\title{
Exogenous application of moringa leaf extract influences growth, flowering and vase life of snap dragon (Antirrhinum majus) cultivars
}

\author{
Abdullah Jan ${ }^{1}$, Fahad Noor ${ }^{1 *}$, Subhan Uddin ${ }^{2}$, Haider Mukhtar ${ }^{1}$, \\ Muhammad Ramzan ${ }^{2}$, Muhammad Raheel ${ }^{1}$, Zahid Hussain ${ }^{3}$ and \\ Shakoor Wisal ${ }^{4}$
}

1. Department of Horticulture, Faculty of Crop Production Sciences, the University of Agriculture Peshawar, KPK, Pakistan

2. Department of Agriculture Mechanization, the University of Agriculture Peshawar, KPK, Pakistan

3. Department of Agronomy, Bacha khan university Charsadda, KPK, Pakistan

4. Department of Human nutrition, Bacha khan university Charsadda, KPK, Pakistan

*Corresponding author's email: fahadnoor795@gmail.com

\section{Citation}

Abdullah Jan, Fahad Noor, Subhan Uddin, Haider Mukhtar, Muhammad Ramzan, Muhammad Raheel, Zahid Hussain and Shakoor Wisal. Exogenous application of moringa leaf extract influences growth, flowering and vase life of snap dragon (Antirrhinum majus) cultivars. Pure and Applied Biology. Vol. 11, Issue 2, pp459-467. http://dx.doi.org/10.19045/bspab.2022.110045

\begin{tabular}{llll}
\hline \hline Received: 03/05/2021 & Revised: $16 / 07 / 2021$ & Accepted: $16 / 08 / 2021$ & Online First: 26/08/2021 \\
\hline \hline
\end{tabular}

\section{Abstract}

Plant-derived bio-stimulants such as Moringa leaves extract are known for increasing the growth and yield of horticultural produce besides having no toxic effects as compared to synthetic fertilizers. Keeping in view its importance a field experiment entitled "Exogenous application of Moringa leaves extract influences growth, flowering and vase life of snapdragon cultivars" was carried out at Malakander Horticulture Research Farm, University of Agriculture Peshawar, Pakistan during winter, 2019. The experiment was laid out in Randomized Complete Block Design with a factorial arrangement having two factors i.e. Cultivars (Potomac and Rocket) and Moringa leaf Extract (MLE) concentrations $(0 \%, 10 \%, 20 \%, 30 \%)$ replicated three times. Cultivars and MLE concentrations significantly affected the studied parameters. Statistical analysis showed that Rocket cultivar produced maximum numbers of leaves plant $^{-1}(126.50)$, stem diameter $(11 \mathrm{~mm})$, plant height $(100 \mathrm{~cm})$, number of florets spike ${ }^{-1}(34)$, flowering duration (39days) and vase life (6days) as compared to Potomac cultivar. Similarly, most number of leaves plant ${ }^{-1}(114)$, stem diameter $(11 \mathrm{~mm})$, plant height $(99 \mathrm{~cm})$, number of florets spike ${ }^{-1}$ (35), flowering duration (44 days), and vase life (8days) was recorded in plants treated with $30 \%$ MLE extract. It is concluded that 30\% MLE for exogenous application and Rocket cultivar for commercial production is recommended in agro-climatic conditions of Peshawar valley.

Keywords: Bio stimulants; MLE concentration; Potomac cultivar; Rocket cultivar

Introduction

Snapdragon (Antirrhinum majus) is a perennial herbaceous ornamental plant but mostly treated as a winter annual seasonal flowering plant [1]. Its family is Plantaginaceae and its origin is the Mediterranean region [2]. Snapdragons are available in varying sizes but mostly they 
are tall attaining a height of 2-3 feet in pots and parterres. Leaves are lanceolate and are 3 inches in length. The Inflorescence is a spike. The dense spikes produce tubular or butterfly-shaped florets. Snapdragon flowers are available in a wide array of colours such as white, purple, red, yellow, orange, pink, and bicolour [3]. Flower spikes can be utilized as a cut flower, alone or in mixed bouquets. Snapdragon is also grown in flower beds in the parks and landscape gardens. Snapdragon is widely recognized in the world for its colourful petals and sweet scent [4].

Chemicals (inorganic fertilizers, pesticides, etc.) used for increasing production are not favourable both for the environment and mankind due to nitrification, leaching and other adverse effects [5, 6]. Inorganic fertilizers quickly release nutrients in the soil which are available to weeds resulting in more infestation of weeds. These weeds then compete with the main crop for water, nutrients, and other resources resulting in decreased production [7]. The increased cost of these chemicals is also a barrier to increasing production $[8,9]$. Overuse of inorganic fertilizers causes soil salinity and causes the plant to spend more energy on water absorption and ultimately the plant completely wilts [10]. These reasons compel the researchers to explore alternate ways for increasing the production of horticultural produce and reduce the reliance on chemical inputs.

One of the ways to increase production is the use of plant-derived bio-stimulants (PDBs). "Plant bio-stimulants are substances and or micro-organisms which stimulate the natural processes to enhance nutrient uptake, nutrient efficiency, tolerance to abiotic stress and crop quality when applied to plants". PDBs can increase plant growth, improve physiological processes which results in increased nutrient uptake, growth, and tolerance to abiotic stresses [11]. Moringa leaf extract
(MLE) is one of the important plant derived bio-stimulant. It is now gaining attention for its growth promoting characteristics. Both macro-and micro-nutrients, such as $\mathrm{N}$, $\mathrm{P}, \mathrm{K}, \mathrm{Ca}, \mathrm{B}, \mathrm{Mg}, \mathrm{Cu}, \mathrm{Zn}, \mathrm{Mn}, \mathrm{Na}$ and $\mathrm{Fe}$ are present in adequate quantities in moringa leaves [12]. MLE is a great source of amino acids, ascorbate, zeatin, minerals, and many other compounds which are responsible for promoting growth. These growth promoters affect plant growth in many ways and improve defence mechanisms against abiotic stresses balancing the endogenous concentration of plant growth regulators [13]. Foliar applications of MLE at different growth stages influence vegetative and floral traits and increase the quantity and size of corms in gladiolus as compared to untreated plants [14]. It also increases plant height, number of branches, leaf area, biomass yield and volatile oil content in geranium as compared to control plants [15]. Experiments with Freesia hybrids shows that corm soaking and foliar application with MLE at 1\%,2\%,3\% and 5\% increased seed germination by $50 \%$, resulted in the tallest plants with shortest production time, the maximum number of flowers, leaf area and cut-flower quality traits and long vase life along with leaf chlorophyll content [16]. Combined applications of MLE and nutrients ( $\mathrm{K}$ and $\mathrm{Zn)}$ results in low fruit drop and increased fruit set, yield, and fruit quality parameters in mandarin [17].

The present experiment was conducted to find the effectiveness of moringa leaf extract on growth, flowering and vase life of snapdragon cultivars suited for commercial production. The study is also an effort to reduce the use of chemicals and explore novel ways to increase production.

\section{Materials and Methods Experimental site}

The field experiment was conducted at Malakander Horticulture Research Farm, 
the University of Agriculture Peshawar Pakistan during November 2019.

\section{Experimental procedure}

Randomized complete block design (RCBD) with two factors was used for the experiment. Factors in the experiment were three MLE concentrations (w/v) $(0 \%($ Control), 10\%, 20\%, $30 \%)$ and two snapdragon cultivars (Rocket and Potomac). Total treatments were eight and total experimental units were 24. There were three replicates. In each treatment there were 10 plants.

\section{Nursery sowing}

The seeds of snapdragon cultivars were bought from a reputed seed store in Peshawar, Pakistan. Seeds were sown in trays in nursery in November 2019 and transplantation to experimental field was carried out in January 2020 when seedling reached the size of 3-4 true leaves. Row to row distance was $60 \mathrm{~cm}$ and plant to plant distance was $30 \mathrm{~cm}$.

\section{Treatment of moringa leaf extract}

Moringa leaves were obtained from Moringa trees of Malakander Farm. The leaves were washed and rinsed with distilled water. The leaves were then crushed using a clean mortar and pestle. The dried leaves were then transferred to the beakers each containing $100 \mathrm{ml}$ of sterile distilled water. The solution was filtered using muslin cloth after 3 hours [18]. Extract concentrations of 10, 20 and $30 \%$ $\mathrm{w} / \mathrm{v}$ were prepared by dissolving $10 \mathrm{~g}, 20 \mathrm{~g}$ and $30 \mathrm{~g}$ of the filtered extract in $100 \mathrm{mls}$ of sterile distilled water in a beaker respectively [19]. The extract was sprayed on the aerial parts of the plant at three stages i.e. 5 leaves, 7 leaves and floral bud stage.

\section{Studied parameters}

Number of Leaves Plant ${ }^{-1}$

It was calculated by counting total number of leaves of the plant throughout life cycle.

Internode length $(\mathbf{c m})$

It was measured by using measuring tape.

\section{Stem diameter (mm)}

It was computed at the base of the plant by Vernier caliper [20].

Plant height (cm)

It was noted from the base to the tip of the plant by measuring tape.

Number of florets spike ${ }^{-1}$

It was calculated by counting total no of florets in a spike.

Spike length (cm)

It was measured with the help of measuring tape.

\section{Flowering duration (Days)}

It was considered from the day of anthesis to the day when most of the florets in the spike were dead and lost its color. Also evaluated visually.

\section{Vase life (Days)}

When lower third of the spike was opened, it was harvested and placed in the vase containing standard sucrose solution. The days were counted from time when the spike was kept in the vase. When 5o\% of the florets were wilted the vase, life was considered terminated [21]. Statistical analysis

The data was recorded and subjected to Factorial Randomized Complete Block Design. Statistix 8.1(statistical analysis software) was used for calculating ANOVA and LSD values [20]. When $F$ values were significant, the mean comparisons were performed by using Least Significance Difference (LSD) test at 5\% level of significance [21].

\section{Results and Discussion}

Number of leaves plant ${ }^{-1}$

Results showed that snapdragon cultivars and MLE concentrations significantly increased number of leaves plant ${ }^{-1}$ while their interaction was found non-significant (Table 1). Among the cultivars, Rocket produced maximum number of leaves plant $^{-1}$ (126.50) as compared to Potomac (79.83). The means for different MLE concentrations showed that foliar spray of $30 \%$ concentration produced maximum 
number of leaves plant ${ }^{-1}(114)$ which was different from other treatments. Minimum numbers of leaves plant ${ }^{-1}$ (91.67) were produced by control $(0 \%)$ treatment. It is obvious from the results that snapdragon plants responded positively to increasing MLE concentrations (0-30\%). This response might be due to higher concentration of cytokinin in MLE which are responsible for cell division and chlorophyll biosynthesis [22]. Moringa leaves are also rich in several micro nutrients such as Magnesium which is constituent of chlorophyll [23]. These Rocket has greater internode length $(2.5 \mathrm{~cm})$ as compared to the internode length $(1.5 \mathrm{~cm})$ of cultivar Potomac. The increase in internode length of cultivars might be due to the genetic makeup. Mean values of internode length for different MLE concentrations also showed significant differences. Highest internode length $(2.5 \mathrm{~cm})$ was recorded for $30 \%$ MLE concentration which was different from other treatments. Minimum internode length $(1.5 \mathrm{~cm})$ was recorded for $0 \%$ (control) treatment. As far as the interaction was concerned the cultivars and MLE concentrations had a non-significant effect. The increase in internode length of cultivars with increasing (0-30\%) MLE concentrations might be because of MLE on stem elongation as MLE increase nutrient uptake and increase growth [10]. The results are also in line with the findings of [27] who reported that MLE at the ratio of 1: 30 resulted an increase in growth parameters of cowpea. [28] also reported an increase in growth and yield of tomato by foliar spray of MLE at the ratio of 1:32.

\section{Stem diameter ( $\mathrm{mm})$}

The data regarding the stem diameter are presented in (Table 1). The statistical findings also agree with [24] who reported that MLE at the rate of $10 \%$ concentration increased the number of leaves plant ${ }^{-1}$ in okra. Similar findings were reported by [25] in sweet corn and [26] in garlic.

\section{Internode length $(\mathrm{cm})$}

Data analysis revealed that the snapdragon cultivars and MLE concentrations significantly influenced the internode length whereas, their interaction showed a non-significant difference (Table 1). Mean values for internode length of cultivar showed that

analysis of the data showed that the stem diameter was significantly affected both in case of snapdragon cultivars and MLE concentrations. The interaction between the cultivars and MLE concentrations was nonsignificant. Between the cultivars, Rocket recorded maximum stem diameter $(11 \mathrm{~mm})$ and minimum stem diameter $(9 \mathrm{~mm})$ was observed for Potomac. In case of MLE concentrations there was significant difference among the means. Maximum stem diameter $(11 \mathrm{~mm})$ was observed in plants sprayed with $30 \%$ MLE concentrations which was different from other treatments and minimum stem diameter $(9.1 \mathrm{~mm})$ was recorded for $0 \%$ (control) treatment. Increase in stem girth might be due to the increase in endogenous concentration of plant hormones such as auxin, gibberellins and cytokinin as moringa leaves are rich in plant hormones especially zeatin [29]. These results are also confirmed by [30] who found improvement in vegetative traits of sacred basil by spraying $2 \%$ MLE with other chemicals. [31] also studied increase in growth of peppers which were treated with exogenous application of MLE at the ratio of 1:10 and $1: 20$. 
Table 1. Foliar spray of MLE influences the growth, flowering and vase life of Snapdragon cultivars

\begin{tabular}{|c|c|c|c|c|}
\hline Treatments & $\begin{array}{c}\text { No of Leaves } \\
\text { plant }^{-1}\end{array}$ & $\begin{array}{c}\text { Internode length } \\
(\mathrm{cm})\end{array}$ & $\frac{\text { Stem Diameter }}{(\mathrm{mm})}$ & $\begin{array}{c}\text { Plant Height } \\
(\mathbf{c m})\end{array}$ \\
\hline \multicolumn{5}{|c|}{ Cultivars } \\
\hline Potomac & $79.83 \mathrm{~B}$ & $1.5 \mathrm{~B}$ & 9B & $77 \mathrm{~B}$ \\
\hline Rocket & $126.50 \mathrm{~A}$ & $2.5 \mathrm{~A}$ & $11 \mathrm{~A}$ & $100 \mathrm{~A}$ \\
\hline LSD at 0.05 & 1.3595 & 0.0749 & 0.07 & 1.17 \\
\hline \multicolumn{5}{|c|}{ MLE concentrations } \\
\hline 0\%(Control) & 91.67D & $1.5 \mathrm{D}$ & $9.1 \mathrm{D}$ & $78 \mathrm{D}$ \\
\hline $10 \%$ & $100.17 \mathrm{C}$ & $1.7 \mathrm{C}$ & $9.5 \mathrm{C}$ & $84 \mathrm{C}$ \\
\hline $20 \%$ & $106.83 \mathrm{~B}$ & $2,2 \mathrm{~B}$ & $10 \mathrm{~B}$ & 93B \\
\hline $30 \%$ & $114 \mathrm{~A}$ & $2.5 \mathrm{~A}$ & $11 \mathrm{~A}$ & $99 \mathrm{~A}$ \\
\hline LSD at 0.05 & 1.9226 & 0.1060 & 0.09 & 1.66 \\
\hline \multicolumn{4}{|c|}{ Interaction } & \\
\hline \multicolumn{5}{|c|}{ C x MLE } \\
\hline Significance & ns & $\mathrm{ns}$ & $\mathrm{Ns}$ & $\mathrm{ns}$ \\
\hline
\end{tabular}

Mean values followed by different letter differ from each other at 5\% level of significance; ns represents nonsignificance

\section{Plant height (cm)}

From the data analyzed it is observed that the snapdragon cultivars and MLE concentrations significantly affected plant height while their interaction was found non-significant (Table 1). Mean values of plant height for cultivars indicated that cultivar Rocket showed the highest plant height $(100 \mathrm{~cm})$ as compared to the plant height $(77 \mathrm{~cm})$ of Potomac. Mean values for MLE concentrations also showed significant difference among them. Highest plant height $(99 \mathrm{~cm})$ was recorded for treatments sprayed with $30 \%$ MLE concentrations which was significantly different from other treatments. Lowest plant height $(78 \mathrm{~cm})$ was noted in control treatment. The interaction between cultivars and MLE concentrations was also significant. Highest plant height $(109 \mathrm{~cm})$ was observed in Rocket sprayed with $30 \%$ MLE concentration whereas minimum plant height $(66 \mathrm{~cm})$ was recorded for Potomac sprayed with 0\% MLE (Control) treatment. The increase in plant height might be due to the higher concentration of amino acids, nutrients and growth hormones in Moringa leaves. This agrees with the findings of [32] who reported that exogenous application of $10 \%$ MLE increased the plant height of the ber plant [33] also concluded that foliar application of MLE at 1:32 concentration increased the plant height in maize. The results are also in accordance with $[34,35]$ who found that exogenous application of MLE increased plant height in tomato and beans

\section{Number of florets spike ${ }^{-1}$}

Data presented in (Table 2) indicated that snapdragon cultivars and MLE concentrations significantly affected number of florets spike ${ }^{-1}$. Their interaction was found non-significant. Maximum number of florets spike ${ }^{-1}$ (34) were recorded in cultivar Rocket as compared to cultivar Potomac (25). There was also significant difference among the means of MLE concentrations. Data analysis showed that exogenous spray of MLE at 30\% resulted in maximum number of florets spike $^{-1}$ (35) which was different from other means. Minimum number of florets spike ${ }^{-1}$ (25) was seen in (0\% MLE) control plot. As MLE is a growth enhancer so it may have 
resulted in increased accumulation of photosynthates which lead to increased reproductive growth. These findings are also reported by [15] who sprayed freesia hybrids with MLE at 1\%,2\%,3\%and 5\% and concluded that maximum number of flowers were produced by treated plants as compared to control. [36] also reported maximum number of flowers in cotton when applied MLE 45 days after blooming. Spike length (cm)

The data regarding spike length of snapdragon stated that cultivars and MLE concentration had a significant effect (Table 2) on the spike length. The interaction between the cultivars and MLE concentration was not significant. Mean value of spike length for cultivars showed that more spike length $(24 \mathrm{~cm})$ was recorded in cultivar Rocket as compared with the spike length $(14 \mathrm{~cm})$ of cultivar Potomac. Though both the cultivars were subjected to same cultural practices and treatments the variation in spike length may be due to their genetic constitution or both cultivars have different receptivity to foliar spray of MLE. Means for MLE concentrations also exhibited significant difference. Plants sprayed with 30\% MLE has taller spikes $(23 \mathrm{~cm})$ which was significantly different from other means. Shorter spikes $(15 \mathrm{~cm})$ were recorded in (0\%MLE) control treatment. This increasing trend exhibited by the plants with the exogenous application of MLE might be due to the presence of gibberellins in moringa leaves. Gibberellins play key role in essential for growth-enhancing activities, flowering initiation and fruit development $[37,38]$.

\section{Flowering duration (days)}

Flowering duration of snapdragon was significantly influenced by cultivars and MLE concentration and their interaction was non-significant as evident from the (Table 2). Data revealed that cultivar rocket exhibited maximum flowering duration of 39 days as compared to cultivar Potomac in which the maximum flowering duration was for 30 days. Among the means of MLE concentrations it was noted that exogenous application of $30 \%$ MLE resulted in longest flowering duration of 44 days. It was significantly different from other means. Shortest flowering duration of 25 days was reported in control plot. The increase in flowering duration may be because of MLE, as it maintained the relative water content in gladiolous as reported by [39]. Limited research has been carried out on extending the bloom period using MLE.MLE should be used in different concentrations and sprayed prior to bloom to check in detail the effect of MLE on extending the bloom period.

\section{Vase life (days)}

The analysis of variance revealed that snapdragon cultivars and MLE concentration had significant effect on vase life (Table 1) and their interaction was found non-significant. The means data for cultivars indicated that maximum vase life (6 days) was observed in the cultivar Rocket as compared to the cultivar Potomac in which the vase life was 5 days. In case of MLE concentrations the means showed that $30 \%$ MLE lead to maximum vase life(8days) and was different from other means. Minimum vase life of 3 days was seen in $(0 \%)$ control treatment. MLE reduce ion leakage and suppress microbial growth at the stem base and might be the reason for longevity of flowers. These findings are also in harmony with [40] who stated that MLE at 1:20 and 1:30 significantly increased the vase life of cut roses by 5 and 8 days as compared to distilled water. [39] reported that spikes treated with $3 \%$ or $4 \%$ MLE extended the vase life by 10 or 9 days as compared to control treatment. MLE is a novel preservative whose role as a flower preservative is not fully known. Role of MLE should be further explored in increasing flower longevity as it is ecofriendly and inexpensive. 
Table 2. Foliar spray of MLE influences the growth, flowering and vase life of Snapdragon cultivars

\begin{tabular}{|c|c|c|c|c|}
\hline \multirow{2}{*}{ Treatments } & No of Florets & Spikee Length & Flowering Duration & Vase Life \\
\hline & spike $^{-1}$ & $(\mathrm{~cm})$ & (days) & (days) \\
\hline \multicolumn{5}{|c|}{ Cultivars } \\
\hline Potomac & $25 B$ & 14B & $30 \mathrm{~B}$ & $6 \mathrm{~B}$ \\
\hline Rocket & $34 \mathrm{~A}$ & $24 \mathrm{~A}$ & $39 \mathrm{~A}$ & $5 \mathrm{~A}$ \\
\hline LSD at 0.05 & 0.8022 & 0.3915 & 0.6191 & 0.4964 \\
\hline \multicolumn{5}{|c|}{ MLE concentrations } \\
\hline 0\%(Control) & $25 \mathrm{D}$ & $15 \mathrm{D}$ & $25 \mathrm{D}$ & $3 \mathrm{D}$ \\
\hline $10 \%$ & $28 \mathrm{C}$ & $18 \mathrm{C}$ & $31 \mathrm{C}$ & $5 \mathrm{C}$ \\
\hline $20 \%$ & $30 \mathrm{~B}$ & 21B & $38 \mathrm{~B}$ & $6 \mathrm{~B}$ \\
\hline $30 \%$ & $35 \mathrm{~A}$ & $23 \mathrm{~A}$ & $44 \mathrm{~A}$ & $8 \mathrm{~A}$ \\
\hline LSD at 0.05 & 1.1344 & 0.5537 & 0.8756 & 0.3510 \\
\hline \multicolumn{5}{|c|}{ Interaction } \\
\hline \multicolumn{5}{|c|}{ Cx MLE } \\
\hline Significance & ns & ns & Ns & ns \\
\hline
\end{tabular}

Mean values followed by different letter differ from each other at 5\% level of significance; ns represent nonsignificance

\section{Conclusion}

It was evident from the study that Rocket cultivar performed better in all studied attributes as compared to Potomac cultivar. As far as the effect of MLE is concerned the results concluded that exogenous application of MLE at $30 \%$ produced the best results. Therefore, MLE at the rate of $30 \%$ for exogenous application and cultivar Rocket for commercial production is recommended in agro-climatic conditions of Peshawar.

\section{Authors' contributions}

Conceived and designed the experiments: S Din \& H Mukhtar, Performed the experiments: F Noor \& A Jan, Analyzed the data: M Raheel \& A Jan, Contributed reagents/ materials/ analysis tools: $\mathrm{Z}$ Hussain, S Wisal \& M Ramzan, Wrote the paper: A Jan \& F Noor.

\section{References}

1. Nawaz MA, Shafique A, Teixeira JA, Ahmed W, \& Saleem BA (2017). Planting time affects vegetative and reproductive growth of exotic cultivars of snapdragon (Antirrhinum majus). Int $J$ Agric Biol 19: 23-28.

2. Bhavya B, Gupta YC \& Sharma P (2016). Performance of Snapdragon (Antirrhinum majus L.) Under Protected and Open Field Conditions in Himachal Pradesh Proc. Natl. Acad. Sci., India. Sect B Biol Sci 86(1): 65-69.

3. Al-Snafi E (2015). The pharmacological importance of Antirrhinum majus-A Review. Asian J Pharma Sci and Tech 5(4): 313-320.

4. Asrar AWA (2012). Effects of some preservative solutions on vase life and keeping quality of Snapdragon cut flowers. J Saudi Soc Agric Sci 11: 29-35.

5. Gomez J, Flores-Felix JD, Garcia-Fraile $\mathrm{P}$, Mateos PF, Menéndez E, Velázquez E \& Rivas R (2018). Probiotic activities of Rhizobium laguerreae on growth and quality of spinach. Sci Rep 8: 295.

6. Ruzzi M \& Aroca R (2015). Plant growth-promoting rhizobacteria act as biostimulants in horticulture. Sci Hortic 196: 124-134.

7. Jama B, Swinkles RA \& Buresh RJ (1997). Agronomic and economic 
evaluation of organic and inorganic phosphorus in western Kenya. Agron $J$ 89: 597-604.

8. Mullins MG (2006). Plant Improvement in Horticulture: The Case for Fruit Breeding, the Regional Institute. pp. 8592.

9. Liu, CW, Sung Y, hen BC\& Lai (2014). Studied the effects of nitrogen fertilizers on the growth and nitrate content of Lettuce. Int J Environ Res Pub Health 11(4): 4427-4440.

10. Posmyk MM \& Szafrańska K (2016). Bio-stimulators: a new trend towards solving an old problem. Front Plant Sci 7:7-48.

11. Yasmeen, Nouman W, Basra SMA, Wahid A, Hussain N, \& Afzal I (2014). Morphological and physiological response of tomato (Solanum lycopersicon $L$.) to natural and synthetic cytokinin sources: a comparative study. Acta Physiol. Plant. 36:3147-3155.

12. Nouman W, Siddiqui MT\&Basra SA (2012). Moringa oleifera leaf extract: An innovative priming tool for rangeland grasses. Turk J Agric 36: 65-75.

13. Younis A, Akhtar MS, Riaz A, Zulfiqar F, Qasim M, Farooq A, Tariq U, Ahsan M, \& Bhatti ZM (2018). Improved cut flower and corm production by exogenous moringa leaf extract application on gladiolus cultivars. Acta Sci Pol 17: 25-38.

14. Ali EF, Hassan FAS, \&Elgimabi M (2018). Improving the growth, yield and volatile oil content of Pelargonium graveolens L. Herit by foliar application with moringa leaf extract through motivating physiological and biochemical parameters. S. Afr. J.Bot. 119: 383-389.

15. Brockman HG (2016). Phytochemical Differences in Western Australia Moringa oleifera Varieties: A Potential for Multi- Product, New Industry Development in the Rangelands, Dept. of Agriculture, WA.
16. Nasir M, Khan AS, Basra SA \& Malik AU (2016). Foliar application of moringa leaf extracts, potassium and zinc influence yield and fruit quality of 'Kinnow'mandarin. Sci Hortic 210: 227 235.

17. Kator L, Oche OD, Hosea ZY \& Agatsa TD (2019). Effect of Aqueous Extract of Moringa Leaves on Postharvest Shelf Life and Quality of Tomato Fruits Inoculated with Fungal Pathogens in Makurdi. Asian J. Agri. and Hort. Res. 3(1): 1-13.

18. Kator L, Terna AC \& Ussuh MW (2019). Effect of Moringa oleifera leaf extract on the postharvest quality of tomato fruits during storage. J. Postharvest T. 7(3): 45-55.

19. Basit A, Shah K, Rahman MU, Xing L, Zuo X, Han M, Alam N, Khan F, Ahmed I \& Khalid MA. (2018). Salicylic acid an emerging growth and flower inducing hormone in marigold (Tagetes sp. L.). Pure and Appl Biol 7(4): 1301-1308.

20. Świder, JR, Skutnik E, Jędrzejuk A \& Wojciechowska JR (2019). Nano silver and sucrose delay the senescence of cut snapdragon flowers. Postharvest Bio. Tech. 165:1165.

21. MT, Shah P, Hollington PA, Khan MJ \& Sohail Q 2009. Agriculture Research: Design and Analysis. Dept. of Agronomy, KPK Agric. Uni. Peshawar, Pakistan.

22. Taiz L, \& Zeiger E (2010). Plant Physiology. Sinauer Associates, Inc, Sunderland, Tshilenge-Lukanda MA, L, Kalonji-Mbuyi, A, Nkongolo, KKC, Kizungu, RV (2013). Effect of gamma irradiation on morpho-agronomic characteristics of groundnut (Arachis hypogaea L.). Am J of Plant Sci 4:21862192.

23. Yameogo, CW, Bengaly, MD, Savadogo, A, Nikiema, PA, Traore \& SA (2011). Determination of chemical composition and nutritional values of Moringa oleifera leaves. Pak J of Nut 10: 264-268. 
24. Kanchani A \& Harris KD (2019). Effect of foliar application of moringa (Moringa oleifera) leaf extract with recommended fertilizer on growth and yield of okra (Abelmoschus esculentus). J Agric East 13(2): 38-54.

25. Fadare K, Ayodeji AF \& SalamI AE (2018). Potentials of Moringa oleifera Leaf Extracts as Biostimulant on the Field Performance of Sweetcorn. J of Biol Agric and Healthcare 8(12): 5056.

26. Abusuwar AO \& Abohassan RA (2004). Influence of Moringa leaf extract on freesia bulbs. J of Agric Sci 9(7): 236243.

27. Maishanu HM, Mainasara MM, Yahaya S, \&Yunusa A (2017). The Use of moringa leaves extract as a plant growth hormone on cowpea (Vigna anguiculata). Path Sci 3: 3001-3006.

28. Culver M, Fanuel $\mathrm{T} \&$ Chiteka AZ (2012). Effect of moringa extract on growth and yield of tomato. Green $J$ Agric Sci 2: 207-211.

29. Elzaawely AA, Ahmed ME, Maswada HF \& Xuan TD (2017). Enhancing growth, yield, biochemical, and hormonal contents of snap bean (Phaseolus vulgaris $L$.) sprayed with moringa leaf extract, Arch Agron Soil Sci 63: 687-699.

30. Prabhu M, Kumar AR \& Rajamani K (2010). Influence of different organic substances on growth and herb yield of sacred basil (Ocimum sanctum L.). Indian $J$ Agric Res 44: 48-52.

31. Matthew A (2016). Moringa leaf extract on the growth and yield of Pepper (Capsicum annuum L.). ARPN J Agric Biol Sci 11: 107-109.

32. Taha LS, Taie, HAA \& Hussein MM (2015). Antioxidant properties, secondary metabolites and growth as affected by application of putrescine and moringa leaves extract on jojoba plants. $J$ of Appl Pharma Sci 5(1): 30-36.

33. Biswas A K, Hoque TS \& Abedin MA (2016). Effects of moringa leaf extract on growth and yield of maize. Progressive Agric 27(2): 136-143.

34. Culver, M, Fanuel, $\mathrm{T} \&$ Chiteka AZ (2012). Effect of moringa extract on growth and yield of tomato. Greener $J$ of Agric Sci 2(5): 207-211.

35. Mvumi C, Tagwira F \& Chiteka AZ (2013). Effect of moringa extract on growth and yield of maize and common beans. Greener J of Agric Sci 3(1): 55-62.

36. Yasmeen A, Arif M, Hussain N, Malik W \& Qadir I (2016). Morphological, growth and yield response of cotton to exogenous application of natural growth promoter and synthetic growth retardant. Int $J$ Agric Biol 18: 1109-1121.

37. Saini RK, Sivanesan I \& Keum Y (2016). Phytochemicals of Moringa oleifera: a review of their nutritional, therapeutic and industrial significance. 3 Biotech 6 : 203.

38. Hedden P (2016). The Gibberellins. Annual Plant Reviews Volume 49 John Wiley \& Sons.

39. Hassan FAS, M, \& Fetouh I (2019). Does moringa extract leaf have preservative effect improving the longevity and post harvest quality of gladiolous cut spikes. Sci Horticult 250: 287-293.

40. Hassan FAS, Mazrou R, Gaber A \& Hassan MM (2020). Moringa extract preserved the vase life of cut roses through maintaining water relations and enhancing antioxidant machinery. $J P$ Harvest Biol Tech 164: 111-156. 